\title{
Implementation of Business Intelligence to Determine Evaluation of Activities (Case Study Indonesia Stock Exchange)
}

\author{
Ali Fajri \\ Widyatama University, Bandung, 40125, Indonesia \\ Email: ali.fajri@widyatama.ac.id \\ Ardiles Sinaga \\ Widyatama University, Bandung, 40125, Indonesia \\ Email: sinaga.diles@gmail.com
}

Received: 11 April 2020; Accepted: 01 November 2020; Published: 08 December 2020

\begin{abstract}
This study aims to examine how to evaluate the activities undertaken in IDX. By building the system "business intelligence implementation to determine the evaluation of activities ". Where in this study also used the algorithm Naive Bayes in the process of data classification activities that have been done. The approach to the development of this software is through the study of libraries, data collection, system design, system implementation, Test systems and analysis. The tools used in the development of this software are Pentaho, PostgreSQL (as a data processing tool), Microsoft Excel (as a tool for creating training data), XAMPP (as a Web server tool) and the encoding used in this software development is the PHP CodeIgniter framework (as the backend), Highcharts (as Dashboard views) and DataTables (as table views). In this study, authors build software that is expected to help the Directorate of Development (RPE) in conducting evaluation activities in IDX. The analysis of the study uses variables from budgetrealization data and activity categories as comparators to figure out the activity status. The study also used IDX activity data in 2018 to implement a built-in system. The results of this study show that the realization of the budget and category of this activity strongly affects the activities that will be evaluated or not evaluated. Activities in each of the IDX representative offices are also potentially to be evaluated, depending on the value of the budget specified in the training data set.
\end{abstract}

Index Terms: Business intelligence, data warehouse, etl, classification, naive bayes classifier, activites evaluation

\section{Introduction}

Indonesia Stock Exchange (IDX) is the party that organizes and provides a system that also provides for bringing together the sale and purchase offers of other parties for the purpose of trading securities between them. One of the socialization and education activities undertaken by the Directorate of Development (RPE) [1-3], through the Investor development and education strategy Unit is to support socialization and education activities that have been implemented well in the Office Representatives throughout Indonesia or the Jakarta area[2,4-8]. To be able to help the effectiveness of activities needed tools consist of reporting system activities that can generate information against several divisions, namely between PIV with PWI [6,9], KEU [10,11], KOM [12,13] and RDP [14]. Activities as part of a program implemented by one or more working units as part of a measured target celebrity on a programme [15]. The organizers of the activities themselves can be agencies, agencies, Governments, organizations, private people, institutions, etc. Similarly, the activities undertaken or carried out by Indonesia Stock Exchange (IDX), which is essentially the activity of Indonesia Stock Exchange (IDX) is occurring in all representative offices which is divided into 34 units based on provinces in Indonesia. The number of activities carried out in the week or per month in a representative office, the reason to be able to apply business intelligence to get an evaluation related to the implementation of an activity the activities of the Indonesia Stock Exchange. Business Inteligence (BI) is defined as the method of converting data into information and subsequently to knowledge [11]. Business Intelligence (BI) has been a top priority of IT executives for several years [23]. The types of knowledge obtained are about the customer requirements and decisions, organizational performance in the industry and the global trends [12]. Another definition of BI, particularly the BI systems is, BI systems put together the gathering and storage of data and knowledge management with analytical tools to present a ready-foraction and complicated information to the planners and decision makers [12]. Business intelligence (BI) refers 
to a managerial philosophy and a tool used to help organizations manage and refine business information with the objective of making more effective business decisions [14]. Business intelligence (BI) has been proliferated due to its increasing contribution to such as business performance determination, data integration from disparate sources, data warehousing, planning, forecasting, budgeting, and the decision making that guides business operation toward desired performance [24]. In determining the evaluation of the activity, it takes a classification of data to be taken a decision whether the activity has been conducted in the evaluation or not. Evaluation is a process of collecting useful information to make decisions and as a benchmark to the extent that objectives can be achieved [13]. From the explanation of the paragraph above, the problems that exist in this study include how to help determine the evaluation of activities in IDX the solution is to build a business intelligence system to determine the evaluation of IDX activities, how to evaluate IDX activities as expected by the solution is to design a business intelligence system that can determine the evaluation of IDX activities, and how the results of the evaluation activity that has been done by determining the evaluation status of activities that have been done by classifying using Naive Bayes algorithm.

As for problem limits in this research include this system is made with the scope of IDX, this system is also made to get decisions about the evaluation status or not of the activities that have been conducted. So in this study will be predicted regarding data analysis to determine the evaluation of the activities with the reference of the determined budget data. Information from business Intelligence will display a graph in the form of a pie or bar showing the activity on each type evaluated by what amount, in each province evaluated how many, at each representative office evaluated how many, this is expected to assist the relevant party, namely IDX to be able to determine the evaluation of the activities that have occurred to be taken a decision that can later affect the activities of conducted by such related representative office. The Following is a stage of research methodology, loaded in Fig. 1.

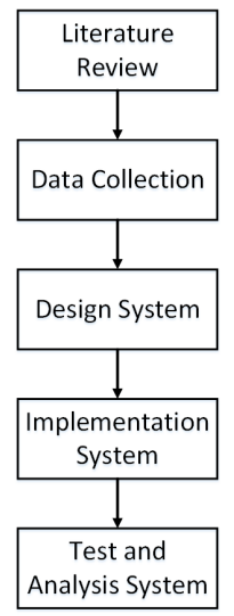

Fig. 1. Research Methodology

- Literature Review, The literature review aims to learn about the basics and methods of the Naive Bayes algorithm, and how to implement it with BI, which is obtained through journals, internet browsing and related readings with good topics Textbook or paper.

- Data Collection, The type of data used for this research is primary data. The primary data itself is data obtained that is collected and processed by itself from the research object. In this research data used is the activity data in 2018 from IDX.

- Design System, The design of this system aims to be able to design the stages of the development of business intelligence to obtain a status of activities.

- Implementation System, Implementation System is the stage of software creation, the continuation of the system design activities. This stage is a stage where the system is ready to operate, consisting of explanations about the implementation environment, and implementation of the program.

- Test and Analysis System, Testing and analysis of systems that have been created with predefined parameters.

\section{Liretarure Review and Materials}

This literature review is about the previous research related to BI, here are some literature reviews that writers have summarized. BI is a neat and systematic process where every organization can acquire, analyse, and disseminate information from significant internal or external sources of information to business activities and for decision making [25]. BI can present business information in a timely and easy-to-consume manner, also providing the ability to reason and understand the meaning behind business information through discovery, analysis, and ad hoc queries [26]. The characteristic of the BI is characterized by a framework that collects, transforms and exhibits organized information 
from various sources. BI is a system and answer that helps decision makers to understand the situation of the company's economy [27]. BI is a framework that converts information into data, then learns.

Thus improving the company's basic decision making process [28]. And the following are supporting materials for the research to be built:

\section{A. Business Intelligence}

Business Intelligence is a series of activities to understand the business situation by conducting various types of analysis on data owned by the organization and external data from third parties to help determine the strategy, decision Business that is tactical, and operational and takes the necessary actions to improve business performance [1].

\section{B. Data Warehouse}

Data Warehouse is a concept and combination of technologies that facilitate organizations to manage and maintain historical data obtained from operational systems or applications. The use of Data Warehouse technology is almost required by all organizations, libraries are no exception. Data Warehouse allows the integration of various types of data from a wide range of applications or systems. This guarantees the mechanism of "one door for management to obtain information, and analyze it for decision making" [2].

\section{ETL}

ETL (Extract, Transform Load) three database functions that are combined into one tool that automates the process to pull data out of one database and place it into another database. The database functions are described following [3]:

\section{Extract}

Extract is the process of reading data from a specified source database and extracting a desired subset of data.

\section{Transform}

Transform is $t$ the process of converting the extracted/ acquired data from its previous form into the form it needs to be in so that it can be placed into another database. Transformation occurs by using rules or lookup tables or by combining with other data.

\section{Load}

Load is the process of writing the data into the target database

\section{Highcharts}

Highcharts could satisfy our needs.It is based entirely on JavaScript.This tool has a relatively low resource overhead, and a faster response speed.Users do not need to install any plug completely, truly cross-platform. Developers are not limited by browser compatibility and development languages [4].

Highcharts written by pure JavaScript. Highcharts is simple and convenient to add interactive charts in the web site or web application. Highcharts interface is aesthetic. HighCharts had a good compatibility. It will be able to support most of the current browsers [5].

\section{E. DataTables}

DataTables works to produce dynamic data tables, where data can be directly sorted by column, besides that with DataTables also provides a search form which directly searches data from all the columns that appear without the need to query from database first [6].

\section{F. Classification}

The model in the classification has the same meaning as the black box, where there is a model that accepts input, then able to do the thought of the input and give the answer as an output of the results of his thinking [7].

1. Models that are already built during training can then be used to predict new class labels that are not yet known. In the construction of models during the training process required an algorithm.

2. The classification prediction is the processing to find a model (or function) that describes and characterizes the concept or class of data, for a particular benefit, that can use modeling to predict which object class the label does not Known.

Classification is a process of finding a model or function that describes or distinguishes the concept or class of data, with the intention of being able to estimate the class of an object whose label is not known. In achieving these objectives, the classification process forms a model capable of distinguishing data into different classes based on specific rules or functions. The Model itself can be a "if-then" rule, a decision tree, or a mathematical formula [8]. 


\section{G. Bayes Classifier}

Bayes is a simple, probabilistic-based predictive technique based on the implementation of the Bayes theorem (or Bayes rule) assuming strong (naïve) independence (independence). In other words, Naive Bayes, the model used is the "independent feature module" [9]. In Bayes (especially Naive Bayes), the intent of a strong independence on the feature is that a different feature in the same data. The Bayes prediction is based on the Bayes theorem with the following general (1):

$$
P(H \mid E)=\frac{P(E \mid H) * P(H)}{P(E)}
$$

Here is a description of the above formula loaded in Table 1.

Table 1. Naive Bayes Classifier

\begin{tabular}{ll}
\hline Parameter & Description \\
\hline $\mathbf{P}(\mathbf{H} \mid \mathbf{E})$ & Conditional end probability (conditional probability) An H hypothesis occurs if the evidence is given by E \\
\hline $\mathbf{P}(\mathbf{E} \mid \mathbf{H})$ & The probability of an E proof occurs affects the H hypothesis. \\
\hline $\mathbf{P}(\mathbf{H})$ & The initial probability (priori) hypothesis H occurs without regard to any evidence \\
\hline $\mathbf{P}(\mathbf{E})$ & Initial probability (priori) proof E occurs regardless of hypotheses/evidence of others
\end{tabular}

The classification with Naive Bayes works on a probability theory that looks out the hallmark of the data as evidence in probability. This gives the characteristics of Naive Bayes as follows [10]:

1. The Naive Bayes method works firmly (robust) against isolated data which is usually a data with different characteristics (outliner). Naive Bayes can also handle wrong attribute values by ignoring the training data during model building process and predictions.

2. Tough facing irrelevant attributes.

3. Attributes that have correlation can degraded the performance of Naive Bayes classification because the independent assumption of the attribute is no longer present.

\section{Designing of Research}

The following is an overview of the system to be built, as shown in Fig. 2 .

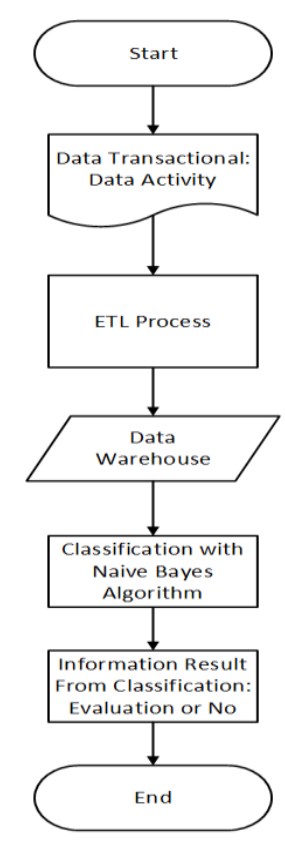

Fig. 2. Overview of Systems built 
In the first phase, collecting transactional data, i.e. the activity data from that already done. Such data include activities data, activity type data, activity category data, representative office data, city data, provincial data and budget realization data. The second stage, perform ETL (Extract Transform Load) on the source data. This ETL process is the data from the source system and presents data in various forms for the transformation process. In this process it is done converting the data into a form of useful format for the transformation process by selecting which attribute to use. Third stage, then the result of ETL goes into the Data warehouse. Fourth stage, after that of data Warehouse then done classification using the Naive Bayes algorithm to determine evaluation of the activities already done, which is displayed in the form of dashboard.

\section{A. Software Requirement}

Software used to implement the system are as follows:

1. The operating system used Windows 10 .

2. The programming language used is PHP Codeigniter.

3. The database used is MySQL.

4. Visual Studio Code (Tools for coding).

\section{B. Profil Company}

Indonesia Stock Exchange (Indonesian: Bursa Efek Indonesia) is a stock exchange based in Jakarta, Indonesia. It was previously known as the Jakarta Stock Exchange (JSX) before its name changed in 2007 after merging with the Surabaya Stock Exchange (SSX). As of October 2019, the Indonesia Stock Exchange had 656 listed companies. In December 2017, based on Single Identification Number there were 628,346 domestic investors, of which 51.33\% were foreign investors and $48.67 \%$ domestic investors. Whereas in December 2019, the total stock investors are 1.1 million and increase 30 percent from previous year. Originally opened in 1912 as Vereniging Voor Effectenhandel In Batavia under the Dutch colonial government acting as a branch of Amsterdamse Effectenbeurs. it was re-opened in 1977 after several closures during World War I and World War II. After being reopened in 1977, the exchange was under the management of the newly created Capital Market Supervisory Agency (Badan Pengawas Pasar Modal, or Bapepam), which answered to the Ministry of Finance. Trading activity and market capitalisation grew alongside the development of Indonesia's financial markets and private sector - highlighted by a major bull run in 1990. On 13 July 1992 , the exchange was privatised under the ownership of Jakarta Exchange Inc. As a result, the functions of Bapepam changed to become the Capital Market Supervisory Agency. On 22 March 1995 JSX launched the Jakarta Automated Trading System (JATS). In September 2007, Jakarta Stock Exchange and Surabaya Stock Exchange merged and named Indonesian Stock Exchange by Indonesian Minister of Finance. The current location of the Indonesian Stock Exchange is located in the IDX building in the Sudirman Central Business District, South Jakarta, near the current site of the Pacific Place Jakarta.

\section{Database}

Databases are the general data management that is computing on software [17]. This IDX database is named Idis database. The table of this Idis data, loading a table from the existing database that has been created where the data in this table, will be taken the table dimensions as needed when designing the table dimensions. Here is a table of Idis databases loaded in Table 2.

Table 2. List Table of Database Idis

\begin{tabular}{ll}
\hline Table Name & Table Component \\
\hline BudgetActivity & Id \\
& Anggaran \\
& AuditTrailld \\
& DataId \\
& DepartmentId \\
& Description \\
& JenisKegiatanId \\
& KantorPerwakilanId \\
& Name \\
& PeriodeAnggaran \\
& State \\
& Id \\
& AuditTrailId \\
& DataId \\
WorkArea & DepartmentId \\
& Description \\
& Name \\
& State \\
\hline
\end{tabular}




\begin{tabular}{|c|c|}
\hline TypeActivity & $\begin{array}{l}\text { Id } \\
\text { AuditTrailId } \\
\text { DepartmentId } \\
\text { Description } \\
\text { Name } \\
\text { State } \\
\text { KategoriKegiatanId } \\
\text { MataAnggaranId } \\
\text { Singkatan }\end{array}$ \\
\hline RepresentativeOffice & $\begin{array}{l}\text { Id } \\
\text { AuditTrailId } \\
\text { DataId } \\
\text { DepartmentId } \\
\text { Description } \\
\text { KodeKP } \\
\text { Name } \\
\text { State } \\
\text { AreaKerjaId } \\
\text { AdminKpId } \\
\text { KanitId }\end{array}$ \\
\hline CategoryActivity & $\begin{array}{l}\text { Id } \\
\text { AuditTrailId } \\
\text { DataId } \\
\text { DepartmentId } \\
\text { Description } \\
\text { Name } \\
\text { State } \\
\text { Order }\end{array}$ \\
\hline BudgetComponent & $\begin{array}{l}\text { Id } \\
\text { AuditTrailld } \\
\text { DataId } \\
\text { DepartmentId } \\
\text { Description } \\
\text { Name } \\
\text { State }\end{array}$ \\
\hline City & $\begin{array}{l}\text { Id } \\
\text { AuditTrailId } \\
\text { DataId } \\
\text { DepartmentId } \\
\text { Description } \\
\text { Name } \\
\text { Provinsild } \\
\text { State } \\
\end{array}$ \\
\hline Province & $\begin{array}{l}\text { Id } \\
\text { AuditTrailld } \\
\text { DataId } \\
\text { DepartmentId } \\
\text { Description } \\
\text { Name } \\
\text { State } \\
\end{array}$ \\
\hline BudgetRealization & $\begin{array}{l}\text { Id } \\
\text { AuditTrailId } \\
\text { DataId } \\
\text { DepartmentId } \\
\text { Description } \\
\text { KegiatanId } \\
\text { KomponenAnggaranId } \\
\text { Name } \\
\text { Nilai } \\
\text { State } \\
\text { Quantity } \\
\text { Keterangan }\end{array}$ \\
\hline
\end{tabular}




\begin{tabular}{|c|c|}
\hline TrxActivity & $\begin{array}{l}\text { Id } \\
\text { AuditTrailId } \\
\text { DataId } \\
\text { DepartmentId } \\
\text { Description } \\
\text { Artikel } \\
\text { KPPenyelenggaraId } \\
\text { LinkPendaftaran } \\
\text { Lokasi } \\
\text { NomorBR } \\
\text { Name } \\
\text { SettlementNumber } \\
\text { TargetOA } \\
\text { State } \\
\text { KuotaPeserta } \\
\text { JenisKegiatanId } \\
\text { KodeKegiatan } \\
\text { Planned } \\
\text { EndTime } \\
\text { StartTime } \\
\text { KotaId } \\
\text { CreatedById } \\
\text { Location } \\
\text { RealisasiEndTime } \\
\text { RealisasiKotaId } \\
\text { RealisasiLokasi } \\
\text { RealisasiPlanned } \\
\text { RealisasiStartTime } \\
\text { CreatedDate } \\
\text { UpdatedDate } \\
\text { RealisasiTargetOA } \\
\text { KantorPerwakilan }\end{array}$ \\
\hline User & $\begin{array}{l}\text { Id } \\
\text { AuditTrailId } \\
\text { DataId } \\
\text { DepartmentId } \\
\text { Description } \\
\text { Name } \\
\text { Password } \\
\text { State } \\
\text { Username }\end{array}$ \\
\hline PasswordHistory & $\begin{array}{l}\text { Id } \\
\text { UserId } \\
\text { Password } \\
\text { Created }\end{array}$ \\
\hline
\end{tabular}

\section{Designing Data Warehouse}

Data Warehouse obtains the data from a number of operational database systems which can be based on RDBMS/ERP Package, etc. The data from these sources are converted into a form suitable for data warehouse [16]. The process of warehousing data is a process used as a basic data for Business intelligence solutions. Therefore, it is necessary to design a data warehouse. Designing the Data warehouse itself is done by forming a new database As formation data to be processed for the implementation of BI. Data used to get the results to be analyzed is adjusted

Problems with this research. The table used is a table associated with the implementation of PT IDX activities. The table used is derived from the initial database of Idis databases, namely TrxActivity, TypeActivity, CategoryActivity, Province, City, Budget Realization. From this table, Not all attributes on the original data are used for the Data warehouse. From the attribute Processed into a data warehouse model, which is a 6 dimensional table

TrxActivity_Dim, TypeActivity_Dim, CategoryActivity_Dim, Province_Dim, City_Dim, BudgetRealization_Dim as well as 1 fact table Idis_fact as shown in Fig. 3.

Fig. 3 above shows the fact table of the Idis database that has been designed. The Data will be used for Extract Transform Load (ETL) process. From the design of the data warehouse indicates that there are 6 dimensions that will process: TrxActivity_Dim, TypeActivity_Dim, CategoryActivity_Dim, Province_Dim, City_Dim, BudgetRealization_Dim 


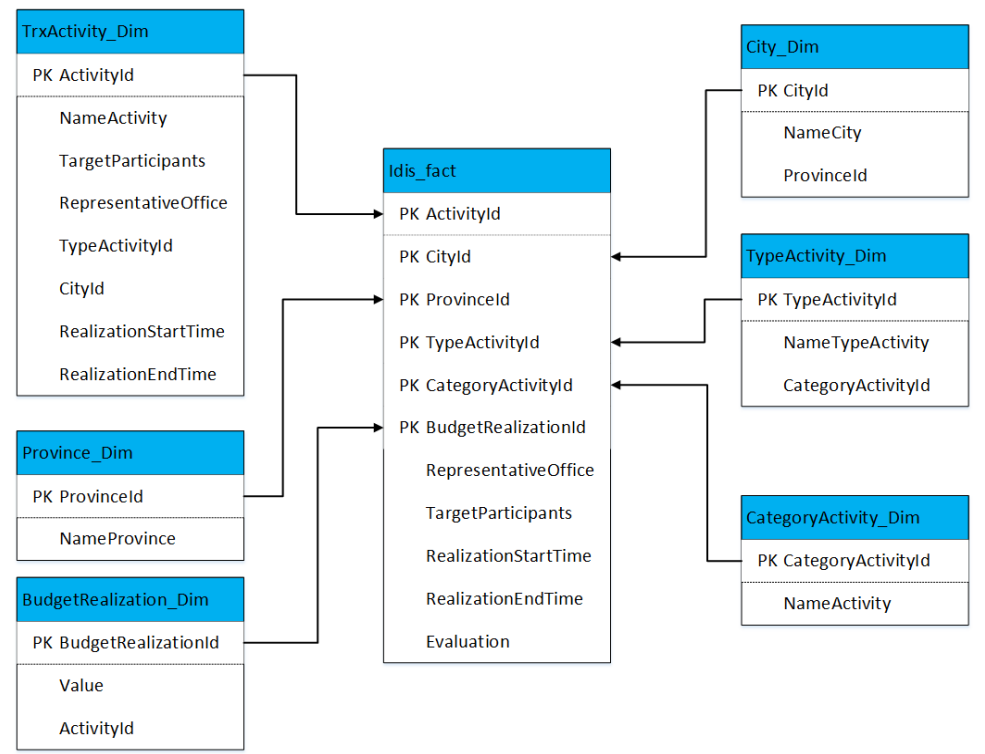

Fig. 3. Idis_Fact Table

\section{Result and Discussion}

\section{A. Implementation Dimension Table}

Dimension tables are strongly denormalized and are used to select the facts of interest based on the user queries. The fact table stores fact attributes its key is defined by importing the keys of the dimension tables [18]. The following are implementations of the created dimensions, where the dimension implementation of this table is sorted by design that has been created on desgining the Data warehouse. Here is a preview of the Created dimension table loaded in Fig. 4.

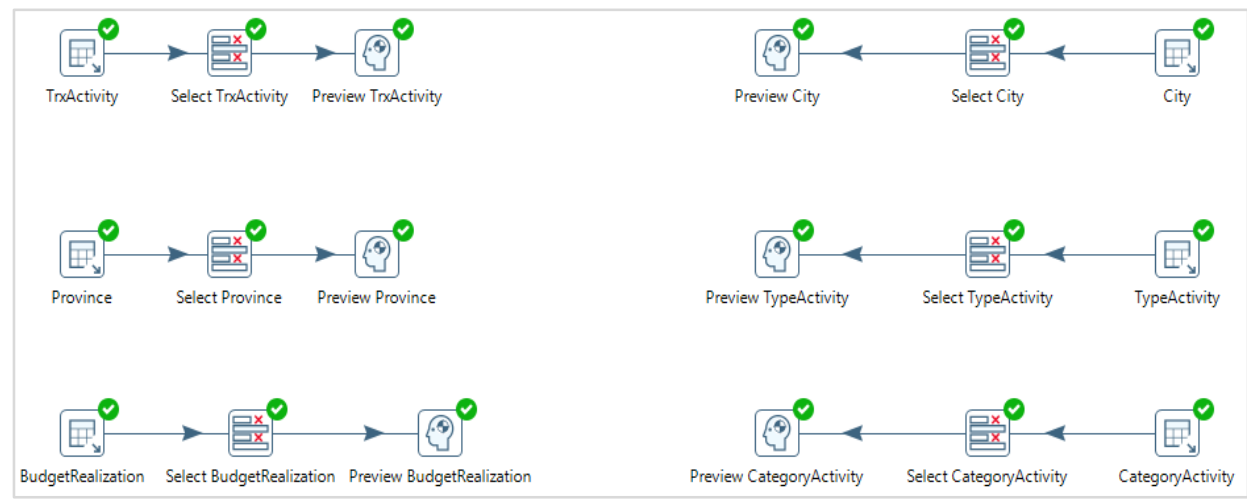

Fig. 4. Implementation Dimension Table

Here are the details of each dimension table that has been created:

1. Fig. 5 will showing implementation the first dimension, namely TrxActivity_Dim 


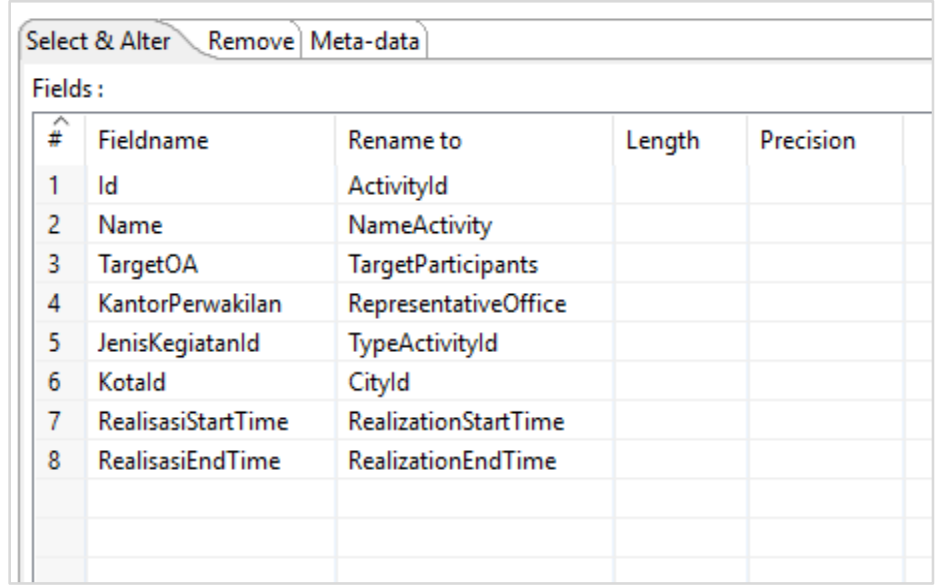

Fig. 5. TrxActivity_Dim

Following is the result data of dimension TrxActivity_Dim in Fig. 6.

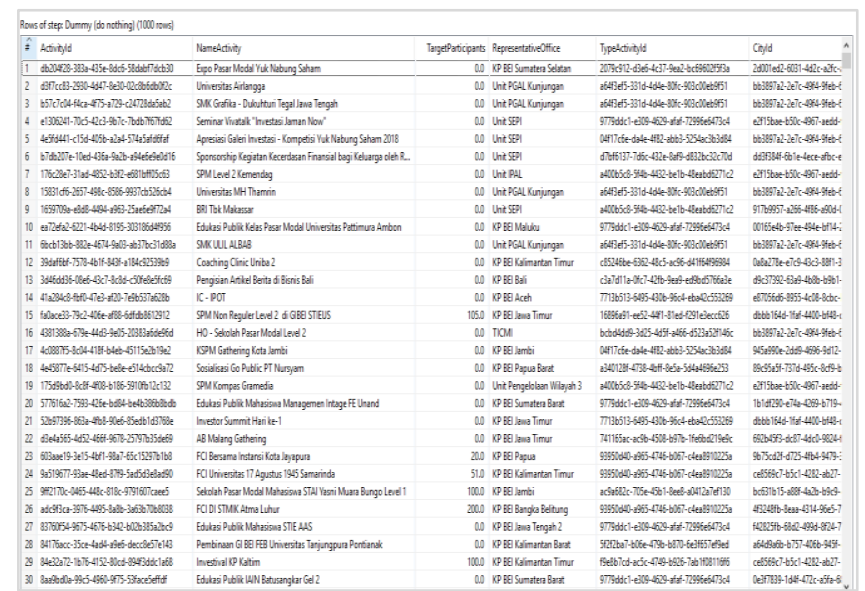

Fig. 6. Result Data of TrxActivity_Dim

2. Fig. 7 will showing implementation the dimension, namely TypeActivity_Dim

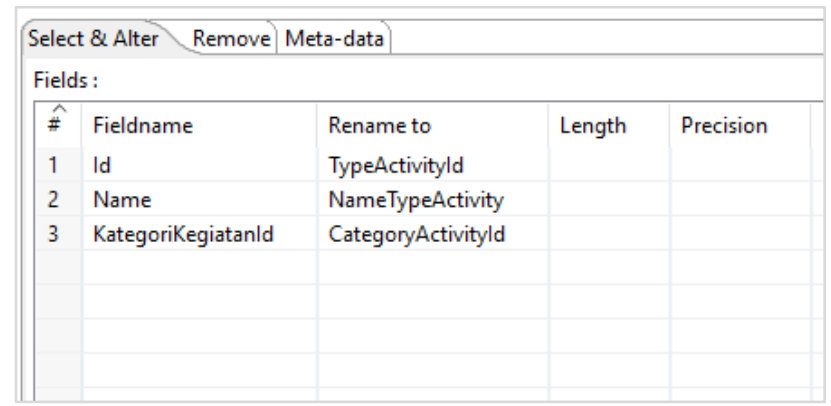

Fig. 7. TypeActivity_Dim

Following is the result data of dimension TypeActivity_Dim in Fig. 8. 


\begin{tabular}{|c|c|c|}
\hline \multicolumn{3}{|l|}{ Rows of ftep: Dummy (do nothing) 3 (52 rows) } \\
\hline$\hat{\#}$ TypeActivityld & NametypeActivity & CategoryActivityld \\
\hline 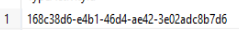 & KP - Sekolah Passr Modal Syariah Level 1 & 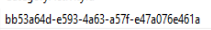 \\
\hline 2 ac96668c-705e-45b1-8ees--80412a7ef130 & KP - Sekolah Pasar Modal Level 1 & 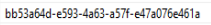 \\
\hline 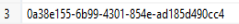 & HO-Sekolah Pasar Modal Level 1 & bb53a64d-E593-4663-257f-e470076e461a \\
\hline 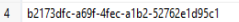 & Media Gathering & 12388328-00f3-455-96ff-147725803c6f \\
\hline 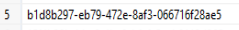 & Edukssi Publik Syyariah & 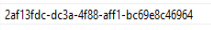 \\
\hline 15f4b300-bb66-4be9-bff-5ceb011302255 & KP - Galley Visit - Pelajar & 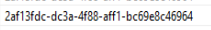 \\
\hline 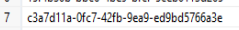 & Media Promosi & 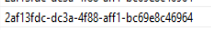 \\
\hline 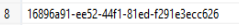 & KP - Sekolah Pasar Modal Level 2 & 1d918d98-6719-477b-8d26-ee58c40defdc \\
\hline $977136513-6495-4306-96 c 4-6 b 342 c 553259$ & Forum Investor & 1d918d98-6199-477b6-8d26-ees8c40defdc \\
\hline 103480 edd7-14c1-4abb-819e-cb893336665b7 & Forum Investor Syariah & 1d9918d98-6199-47b6-8d26-ee58c400dfdc \\
\hline 11 3663ddet-6091-4bec-8d7c-96c3dctcb7ees & Workshop & 1d918d99-6619-47b6-8d26-ees8c400defdc \\
\hline 12 03409999-ef69-4957-2270-29(c49e13ffi) & KP - Galley Visit - non pelajar & $2 a f 13 f d d-d c 33-4 f 88-a f f 1-b 669 e 8 c 46964$ \\
\hline 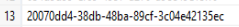 & CSR & 12388828-00f-4555-96fb-1477258033cff \\
\hline 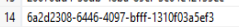 & Lainrya & 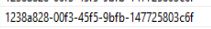 \\
\hline 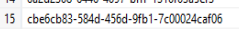 & Sponsorship Galeri Investasi (GI) & 1e8455a9-0251-49ce-9734-65e8ecod28aа \\
\hline 16 d7bb6137-7d6c-432e-8fag-d832bc32c70d & Sponsorship Non-Galen Investas (Non-GI) & 1e8455a9-0251-49ce-9734-65e8ecod28sa \\
\hline 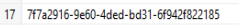 & HO - Gallery Vsiti - non pelajar & 2af13fdc-dc33-4f88-aff1-bc69e8c449964 \\
\hline 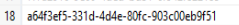 & HO - Gallery Visit- Pelajar & 2aff13fdc-dc3a-4ff88-aff1-bcr69esc46964 \\
\hline 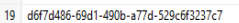 & Investor Summit/ Public Expose & 1 1d918d98-6619-47b6-8d26-ees8c400dffc \\
\hline 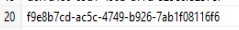 & INVESTVAL YNS KP & 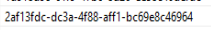 \\
\hline 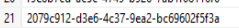 & Branding Yuk Nabung Saham Kantor Perwakilian & 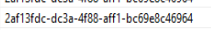 \\
\hline 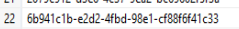 & Relaunching Galeri Investasi & 97ddff16-9175-4034-8811-0c604547335t2 \\
\hline 23 d12412128-1860-4cec-a932-d2dteeceb555 & Training Sertifikasi WPPE/WMI & c8e5993c-afed-45e7-bbc9-b326819740899 \\
\hline 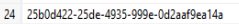 & Ujian Sertfikasi WPPE/WMI & c8e5993c-afed-45e7-bbc9-b32681974039 \\
\hline 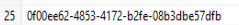 & Keja sama TICMI - Universitas & cees993e-afed-45e7-bbeg-b32681974089 \\
\hline 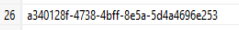 & Sosialissss Go Public One on One & 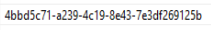 \\
\hline 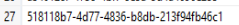 & Business Meeting & $4 b b d 5 c 71-8239-4 c 19-8643-7 e 3 d f 269125 b$ \\
\hline 28 Oodd7742-5067-457-2485-50587e5887727 & Peresmin G B BEI & 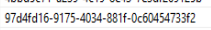 \\
\hline 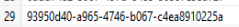 & KP- Forum Salon Investor & be53a64d-e593-4663-257f-44700766461a \\
\hline 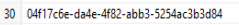 & GI Gathering & 12388828-0073-4555-96fb-147725803ceff \\
\hline
\end{tabular}

Fig. 8. Result Data of TypeActivity_Dim

3. Fig. 9. will showing implementation the dimension, namely CategoryActivity_Dim

\begin{tabular}{|c|c|c|c|c|}
\hline \multicolumn{2}{|c|}{ Select \& Alter Remove } & \multicolumn{2}{|l|}{ Meta-data } & \\
\hline \multicolumn{5}{|c|}{ Fields : } \\
\hline $\begin{array}{l}\hat{\#} \\
1\end{array}$ & $\begin{array}{l}\text { Fieldname } \\
\text { Id }\end{array}$ & $\begin{array}{l}\text { Rename to } \\
\text { CategoryActivityld }\end{array}$ & Length & Precision \\
\hline 2 & Name & NameCategory & & \\
\hline & & & & \\
\hline & & & & \\
\hline & & & & \\
\hline
\end{tabular}

Fig. 9. CategoryActivity_Dim

Following is the result data of dimension CategoryActivity_Dim in Fig. 10.

\begin{tabular}{|c|c|c|c|}
\hline \multicolumn{4}{|c|}{ Rows of step: Dummy (do nothing) 4 (10 rows) } \\
\hline$\hat{\#}$ & CategoryActivityld & NameCategory & \\
\hline 1 & 2af13fdc-dc3a-4f88-aff1-bc69e8c46964 & Literasi & \\
\hline 2 & bb53a64d-e593-4a63-a57f-e47a076e461a & Inklusi & \\
\hline 3 & 1d918d98-61f9-47b6-8d26-ee58c40defdc & Aktivasi & \\
\hline 4 & 1e8455a9-0251-49ce-9734-65e8ec0d28aа & Sponsorship & \\
\hline 5 & 4604d4ce-d1d8-4be1-ae8f-67a9387ce8dc & GI-AB Gathering & \\
\hline 6 & 97d4fd16-9175-4034-881f-0c60454733f2 & Peresmian Galeri Investasi & \\
\hline 7 & 1238a828-00f3-45f5-9bfb-147725803c6f & Lainnya & \\
\hline 8 & 4bbd5c71-a239-4c19-8e43-7e3df269125b & Pengembangan Calon Emiten & \\
\hline 9 & c8e59f3c-afed-45e7-bbc9-b32681974089 & Kerjasama dengan TICMI & \\
\hline 10 & e6824e50-27a9-403c-b473-771ff851166a & Pendalaman Pasar Modal & \\
\hline & & & \\
\hline & & & \\
\hline
\end{tabular}

Fig. 10. Result Data of CategoryActivity_Dim

4. Fig. 11. will showing implementation the dimension, namely Province_Dim

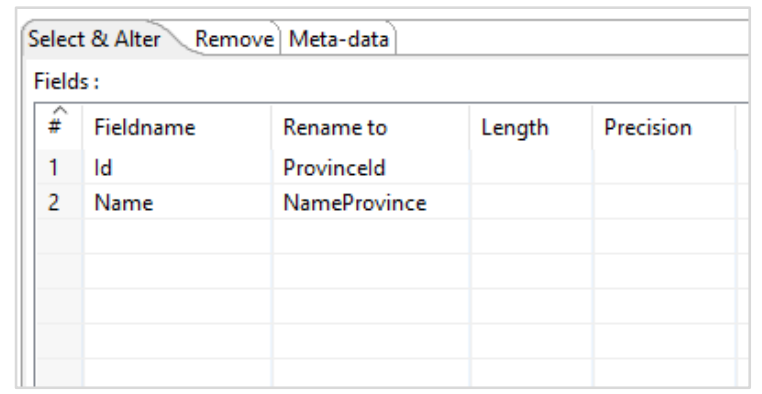

Fig. 11. Province_Dim 
Following is the result data of dimension Province_Dim in Fig. 12.

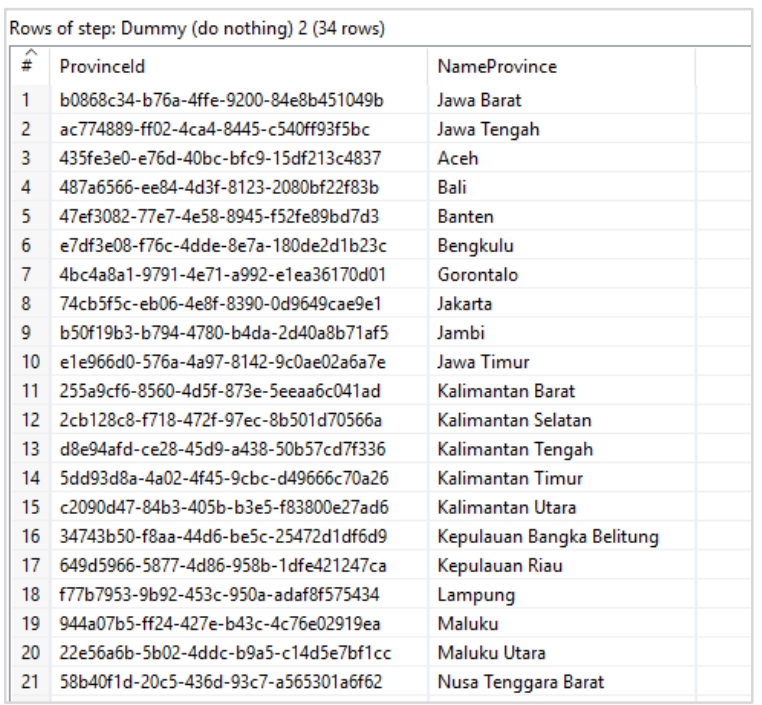

Fig. 12. Result Data of Province_Dim

5. Fig. 13 will showing implementation the dimension, namely City_Dim

\begin{tabular}{|c|c|c|c|c|}
\hline \multicolumn{2}{|c|}{ Select \& Alter Remove } & Meta-data & & \\
\hline \multicolumn{5}{|c|}{ Fields : } \\
\hline $\begin{array}{l}\text { \# } \\
1\end{array}$ & $\begin{array}{l}\text { Fieldname } \\
\text { Id }\end{array}$ & $\begin{array}{l}\text { Rename to } \\
\text { Cityld }\end{array}$ & Length & Precision \\
\hline 2 & Name & NameCity & & \\
\hline 3 & Provinsild & Provinceld & & \\
\hline & & & & \\
\hline & & & & \\
\hline & & & & \\
\hline & & & & \\
\hline & & & & \\
\hline & & & & \\
\hline
\end{tabular}

Fig. 13. City_Dim

Following is the result data of dimension City_Dim in Fig 14.

\begin{tabular}{|c|c|c|c|}
\hline \multicolumn{4}{|c|}{ Rows of step: Dummy (do nothing) 6 (1000 rows) } \\
\hline$\hat{\#}$ & Cityld & NameCity & Provinceld \\
\hline 1 & 08b3cfb3-f509-4d9e-8cfa-dde $1320225 b c$ & Bangli & 487a6566-eee84-4d3f-8123-2080bf22f83b \\
\hline & fc89290f-84a9-4981-a597-c0ea13abf986 & Buleleng & 487a6566-ee84-4d3f-8123-2080bf22f83b \\
\hline 3 & d9c37392-63a9-4b8b-b9b1-f5a0a922028d & Denpasar & 487a6566-ee84-4d3f-8123-2080bf22f83b \\
\hline 4 & e4cbb100-c551-4c08-addd-378745dd03d7 & Gianyar & 487a6566-ee $84-4 d 3 f-8123-2080$ bf 22f8sb \\
\hline 5 & 190485db-a322-41 c0-961c-3a405dcefc7c & Jembrana & 487a6566-ee84-4d3f-8123-2080bf22f83b \\
\hline 6 & f28cc9f1-3736-47ab-bef0-73358fffffafo & Karang Asem & 487a6566-ee84-4d3f-8123-2080bf22f83b \\
\hline 7 & ab54407f-cf64-4e87-ac6a-19897b9274c9 & Klungkung & 487a6566-ee84-4d3f-8123-2080bf22f83b \\
\hline 8 & dd649e70-6498-4dd1-9bd2-096d6fdbe37f & Tabanan & 487a6566-ee84-4d3f-8123-2080bf22f83b \\
\hline 9 & a8cb755e-9d3f-4e82-82f5-5eaa 12bd3cae & Cilegon & 477ef3082-77e7-4e58-8945-f52fe $89 \mathrm{bd} 7 \mathrm{~d} 3$ \\
\hline 10 & $c 7 d a 81 e 2-1 b c 2-4488 c-a 0 e 7-b 5966432 c \mathrm{cda} 2$ & Lebak & 47ef3082-77e7-4e58-8945-552feg9bd7d3 \\
\hline 11 & 208ecefc-8e12-4717-abdc-8833b4abda0b & Pandeglang & 47ef3082-77e7-4e58-8945-552fe89bd7d3 \\
\hline 12 & a 79 da $07 b-5065-45 d a-a 7 d e-1 e 0273 a 5 c 2 c 6$ & Serang & 47ef3082-777e-4es5-8945-f52fes9bd7d3 \\
\hline 13 & 8d48e915-f095-4f65-a7b3-6d23ffc3fa7f & Tangerang & 47ef3082-77e7-4e58-8945-f52feg9bd7d3 \\
\hline 14 & $2 \mathrm{bd} 3 \mathrm{~b} 222-2777-433 \mathrm{e}-\mathrm{b} 15 \mathrm{c}-336 \mathrm{~d} 080 \mathrm{c} 19 \mathrm{~b} 8$ & Tangerang Selatan & $47 \mathrm{e} 3082-77 \mathrm{e}-4-4 \mathrm{e} 58-8945-552 \mathrm{fe} 89 \mathrm{bd} 7 \mathrm{~d} 3$ \\
\hline 15 & 30d52350-cef0-4eec-be 17-6e40daeb05bc & Bengkulu & e7df3e08-f76c-4dde-8e7a-180de2d1b23c \\
\hline 16 & $6 f a 40 c 16-4 d 93-459 c-$-a5bd-5fd51ad5a648 & Bengkulu Selatan & e7df3e08-f76c-4dde-8e7a-180de2d1b23c \\
\hline 17 & ac4eb22f-112e-4924-b231-f7ece8e4806f & Bengkulu Tengah & e7df3e08-f76c-4dde-8e7a-180de2d1b23c \\
\hline 18 & 3f2cb179-bee4-4c67-9fc4-a438fe 176fda & Bengkulu Utara & e7df3e08-f76c-4dde-8e7a-180de2d1b23c \\
\hline 19 & 404516d5-da4c-4df4-bb24-eeb8c0190fbf & Kaur & e7df $3=08-f 76 c-4 d d e-8 e 7 a-180 d e 2 d 1 b 23 c$ \\
\hline 20 & 6d6bc963-0735-449b-8c12-14be59c0d71e & Kepahiang & e7df3e08-f76c-4dde-8e7a-180de2d1b23c \\
\hline & f608a 1b1-8468-4154-8319-5df2181fbce4 & Lebona & e7df3en8-776c-4dde-8e7a-180de2d1b23c \\
\hline
\end{tabular}

Fig. 14. Result Data of City_Dim

6. Fig 15. will showing implementation the dimension, namely BudgetRealization_Dim 


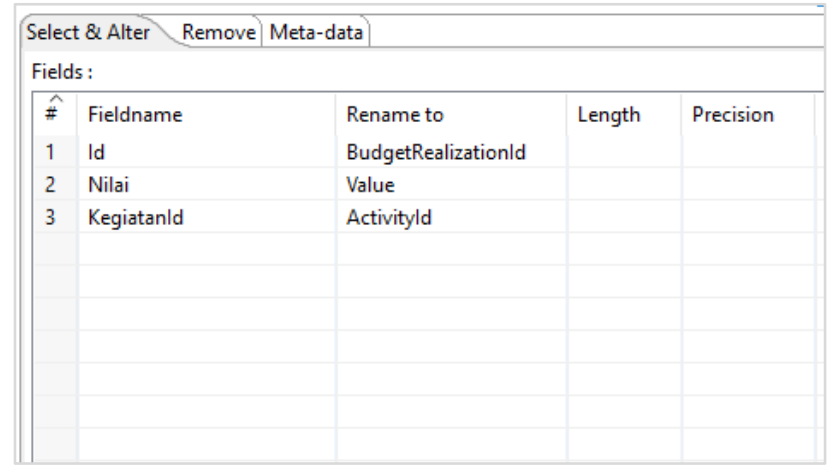

Fig. 15 BudgetRealization_Dim

Following is the result data of dimension BudgetRealization_Dim in Fig. 16.

\begin{tabular}{|c|c|c|c|}
\hline \multicolumn{4}{|c|}{ Rows of step: Dummy (do nothing) 7 (1000 rows) } \\
\hline$\hat{\#}$ & BudgetRealizationld & Value & Activityld \\
\hline 4 & 7d956198-8282-4158-9355-7dacd5b6981b & 200000.0 & $d 4 b 1586 b-6 a 68-4 b 95-a 57 a-21 c 1 b 0 a 5 f 864$ \\
\hline 5 & 07431225-4fef-4d01-a337-f9e22c7ac77a & 2716000.0 & $1 \mathrm{cb} 7 \mathrm{c} 613-180 \mathrm{c}-4519-9 \mathrm{~b} 4 \mathrm{e}-\mathrm{b} 57 \mathrm{e} 2 \mathrm{~d} 7056 \mathrm{e} 4$ \\
\hline 6 & 2d860553-5268-43ee-9120-c2e3aeb1c40e & 250000.0 & 47d72ebf-3017-4a8a-bec6-0adf5effa532 \\
\hline 7 & аса37599-b88e-4773-9c62-1707eba35490 & 600600.0 & $3 \mathrm{~b} 14 \mathrm{f} 776-35 f 2-4 \mathrm{c} 9 \mathrm{a}-87 \mathrm{~d} 2-\mathrm{e} 4588 \mathrm{~d} 02034 \mathrm{~d}$ \\
\hline 8 & $d 608216 b-2 e 39-4595-a 6 c 8-3 b 425 b 125 b 16$ & 150000.0 & $2 f 5246 c 1-95 c e-4 d e e-88 b 7-15 b d a 571 a e b 4$ \\
\hline 9 & 9f8c9d04-81b3-4d91-bf00-d6a0fff48031 & 250000.0 & c7c1e4e5-a974-4024-8b43-8974e08fe3f5 \\
\hline 10 & $565 f 66 f 7-37 b 4-40 c 6-8404-124 b 7 b 059 e d a$ & 669000.0 & 155c30d5-78f5-4b16-b6f3-e7c7ac720d5a \\
\hline 11 & 09ff8c67-d913-4733-b808-a0c89fffebc4 & 750000.0 & 04ecc26e-a259-40db-9e74-36cb06f634be \\
\hline 12 & 47668bd5-d286-444b-a8b9-6a7fd560184b & 14355.0 & a53a8840-98ca-4178-8033-0cfc38087395 \\
\hline 13 & 7e758cbf-69cf-4b19-b72a-646e66a365e6 & 232500.0 & $\mathrm{~d} 0 \mathrm{a} 4 \mathrm{e} 698-157 \mathrm{e}-4747-8 \mathrm{~d} 37-67 \mathrm{ccfd} 246139$ \\
\hline 14 & 8ce83bfe-3746-41c2-b829-95bccc7dbca2 & 2500000.0 & 02220116-d9da-4aa4-96cd-c4fffa20ae 70 \\
\hline 15 & $9 a 6004 c 7-1227-46 \mathrm{df}-9424-\mathrm{a} 4982 \mathrm{cc} 09158$ & 180000.0 & $00 c 8 f 05 b-4988-4326-a f b d-2 a b 9 e d 60584 b$ \\
\hline 16 & Oc29141a-762f-4b13-b185-de0c3bbce4c1 & 30000.0 & 6ce0dd16-eddf-4ed7-9639-9c61392dc9d8 \\
\hline 17 & 6d3730a4-2344-4c72-ad0c-a8045d1c7359 & 8700.0 & d9173108-fed0-4190-b84b-3e919d3abfb9 \\
\hline 18 & $2 f \mathrm{~b} 10361-92 \mathrm{a} 8-4372-82 f 5-f 8 c 124 d c 7121$ & 331000.0 & 639f6b1f-6640-40b2-b7c5-9fbfa302498e \\
\hline 19 & 9c4444c7-c059-4511-b8be-3609cc855f8a & 450000.0 & $822 \mathrm{~b} 7438-\mathrm{b} 22 \mathrm{~d}-446 \mathrm{~b}-\mathrm{a} 4 \mathrm{~b} 6-\mathrm{c} f 43 \mathrm{e} 869 \mathrm{dd} 80$ \\
\hline 20 & c0060248-bbe5-4083-aef4-10adcb99d2d3 & 19000.0 & $3 b 5 f 843 b-f 13 b-48 a d-9 a 63-d 2610782 a 93 c$ \\
\hline 21 & $5 b 96579 \mathrm{e}-1 \mathrm{a} 52-4 \mathrm{c} 34-9 \mathrm{e} 96-1 \mathrm{~b} 7968626 \mathrm{cb} 5$ & 18150.0 & $36 f 88 c 47-b 3 a 5-4858-b f 3 e-b 48 b b 92 c f 627$ \\
\hline 22 & f94e40ab-4681-44af-85e8-573d316cc21a & 1740000.0 & 036de43e-e539-48d3-acf0-6cf1384072ee \\
\hline 23 & $5108 f b 08-381 e-466 c-8 c c 8-6927 c e 064 b c 3$ & 2212500.0 & 16b3b4df-e365-43c4-a $779-b f 19 e 981 e e 5 d$ \\
\hline 24 & $32867 c 7 c-c 782-4821-9550-9001 b 102 c d a 1$ & 9570.0 & 46fe3892-3916-4cac-a05f-aea 12a7e2429 \\
\hline 25 & $31 \mathrm{~d} 728 \mathrm{~b} 0-9688-443 \mathrm{a}-95 \mathrm{df}-2 \mathrm{ddb} 37 \mathrm{a} a 1249$ & 1671000.0 & $54 d 6 c 020-988 d-48 c a-9 a 0 b-194733 f 16 a 95$ \\
\hline 26 & $8 c 015140-38 d d-47 b e-9 f 40-9 d 9 e 79282 d 42$ & 1100000.0 & f94464d6-b361-4508-a1fa-3384d0f8c7c6 \\
\hline 27 & a03b66cd-10df-4a3c-9b03-67b9cff676af & 348000.0 & $2 e 669$ afb-be $46-41 b c-a 426-c a f d d f c e 5 e d 1$ \\
\hline 28 & Ofa8f758-12bf-4941-b95a-467585d44827 & 540200.0 & Oeb7e7fe-9964-4705-ab71-3279f0453a0e \\
\hline 29 & ébceae5-99c9-4ea8-a221-b1de8295e268 & 6894000.0 & cc384340-24e5-4f47-a268-e10e96704f75 \\
\hline 30 & $31 \mathrm{fa} 0922-710 c-4 b 4 e-882 b-e 9945 e 9 c f d 4 c$ & 31602000.0 & 7b615497-511a-4a58-8f44-1bacbc9575f5 \\
\hline
\end{tabular}

Fig. 16. Result Data of BudgetRealization_Dim

\section{B. Implementation ETL}

ETL processes take up to $80 \%$ of the effort in BI projects [19]. A high performance is thereby vital to be able to process large amounts of data and to have a up-to-date database [20]. On the implementation of ETL (Extract Transform load) load the dimension table created in the previous step.. Here is an implementation of the built-in etl loaded on Fig. 17 Implementation ETL:

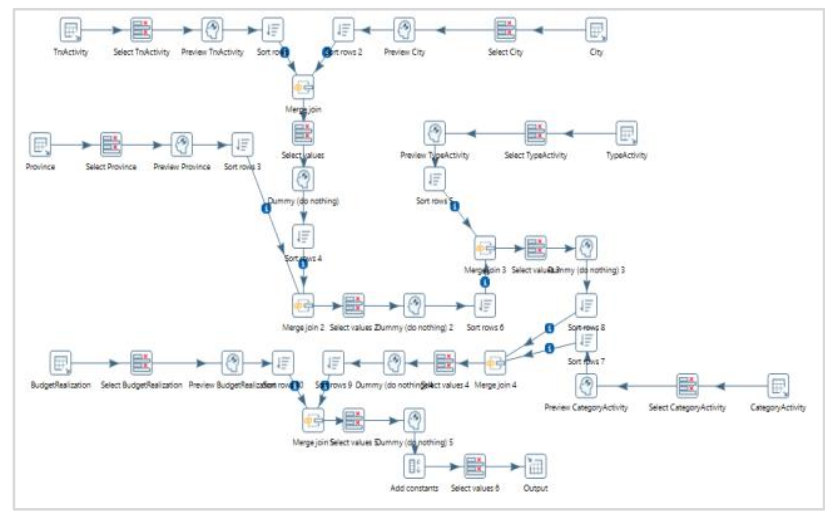

Fig. 17. Implementation ETL 
From the picture above, it can be seen that in the process of implementing ETL is done merging of the created dimension table, then obtained the output according to the design of the fact table that has been created.

\section{Implementation Naive Bayes}

Naive Bayes is among the simplest probabilistic classifiers. It often shows amazingly well in many real-world applications, in the face of the strong assumption that all features are provisionally independent given the class [21]. In this Naive Bayes implementation there are several steps to do. Here is an implementation of the built-in naive bayes classifier:

1. Define the training data, which contains predefined training data that is in the form of spreadsheet files. Loaded on Fig. 18.

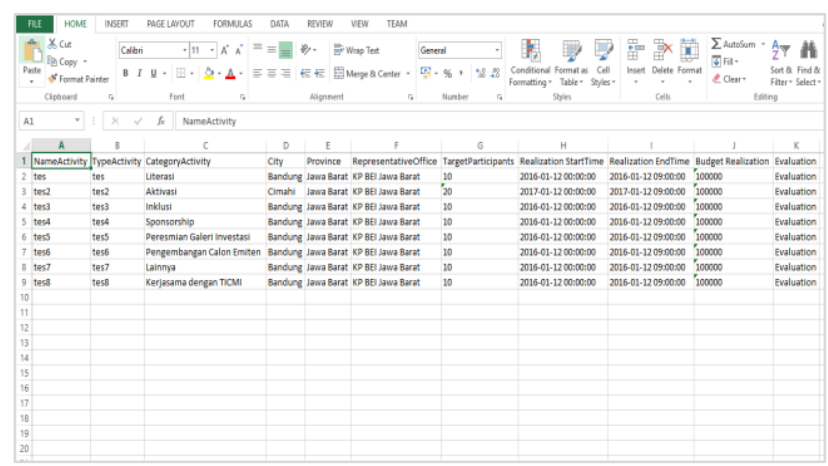

Fig. 18. Data Training File Shapes Spreadsheet

2. Upload your spreadsheet file training data into the system. Loaded on Fig. 19.

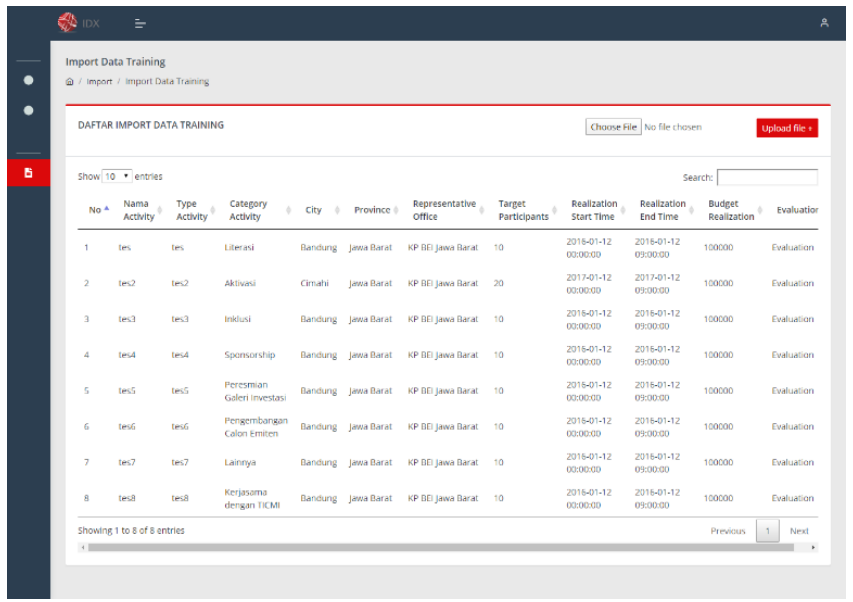

Fig. 19. Uploading Files Data Training

3. Specifying data testing, extracted from data already displayed on the original dashboard. Loaded on Fig. 20.

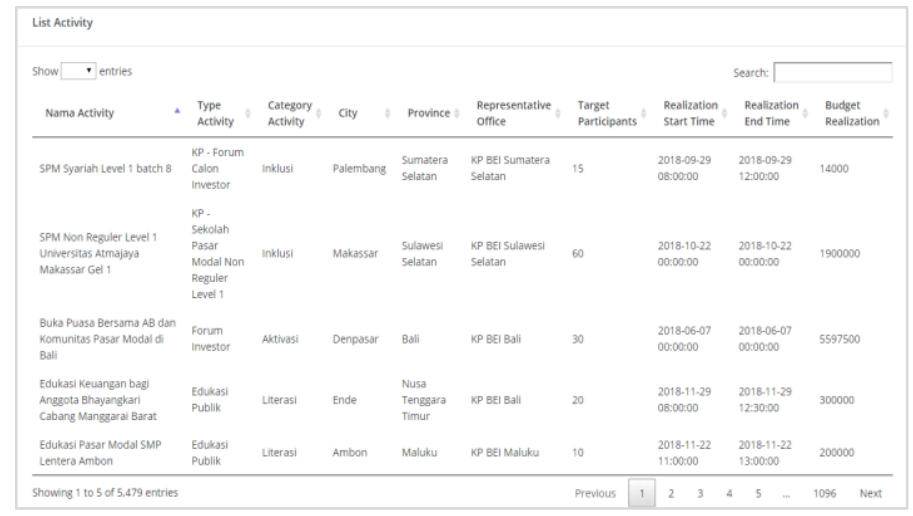


4. Comparing data between training data and later data testing, the results will be noticeable where activities should be evaluated and activities that should not be evaluated. Loaded on on Fig. 21

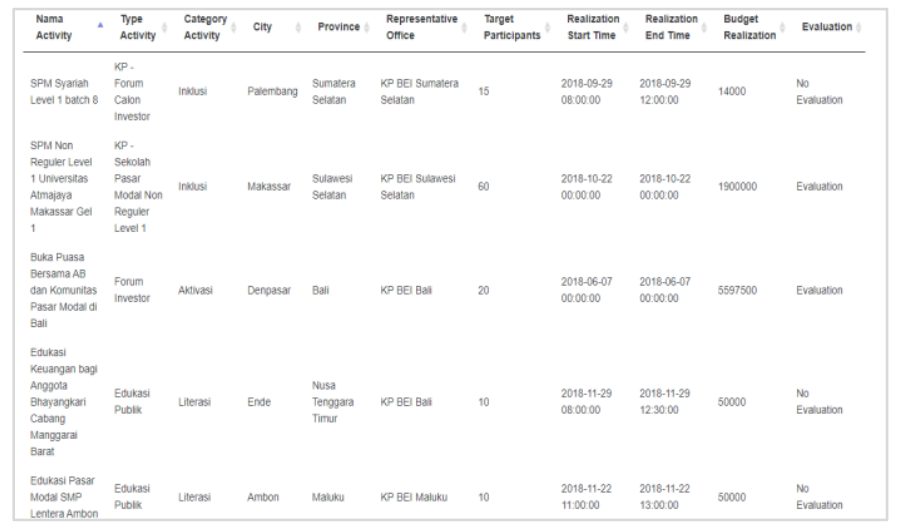

Fig. 21. Result Compare Data Training \& Data Testing

\section{Implementation Intelligence Dashboard}

Intelligence Dashboard can be used for data analysis and decision making [22]. On the implementation of this dashboard intelligence, there are 2 dashboards displayed. Here is an implementation of the built-in intelligence dashboard:

\section{Dashboard Original}

Dashboard Original this is dashboard that displays the original data of activities or data activities that have not been applied classification activity evaluation. Loaded on Fig. 22.

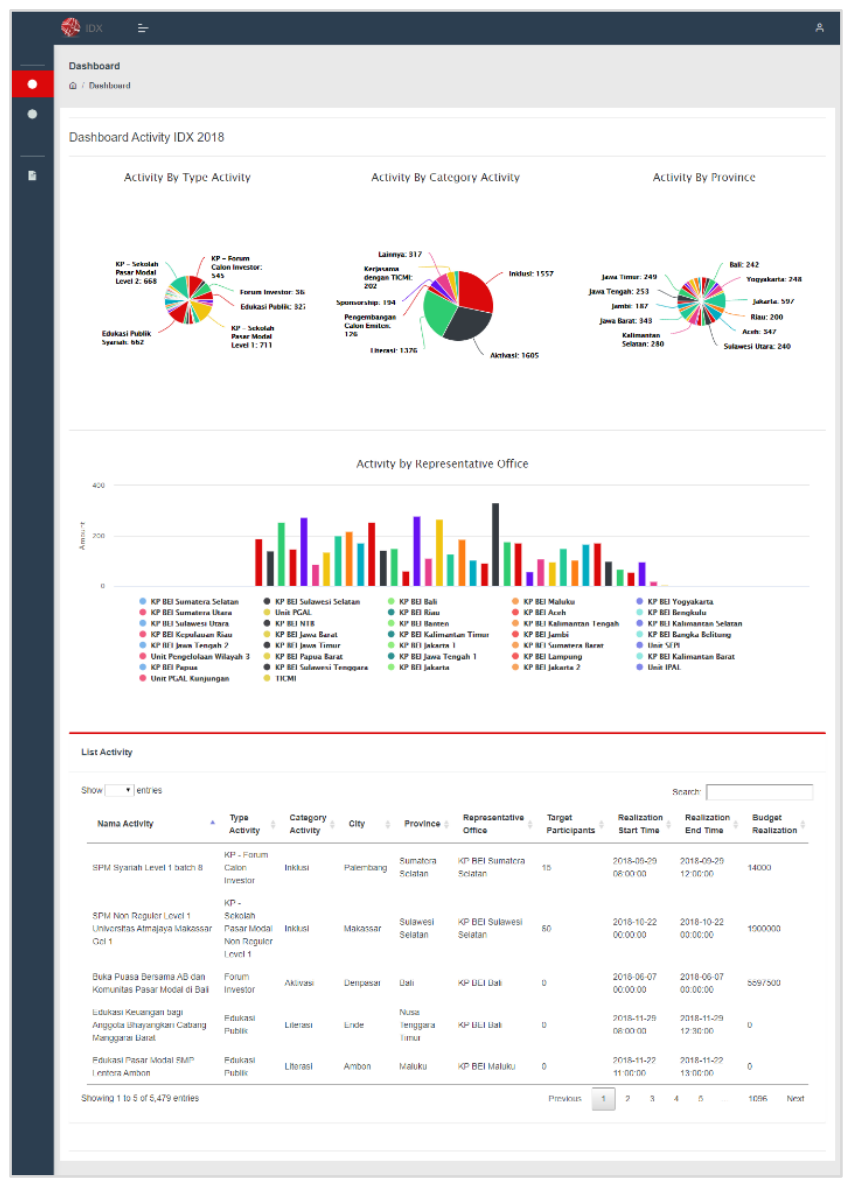

Fig. 22. Implementation Intelligence Dashboard Activity Originial 


\section{Dashboard Evaluation}

Dashboard Evaluation this dashboard that displays activity data that has been evaluated and activity data that does not include evaluation. Loaded on on Fig. 23.

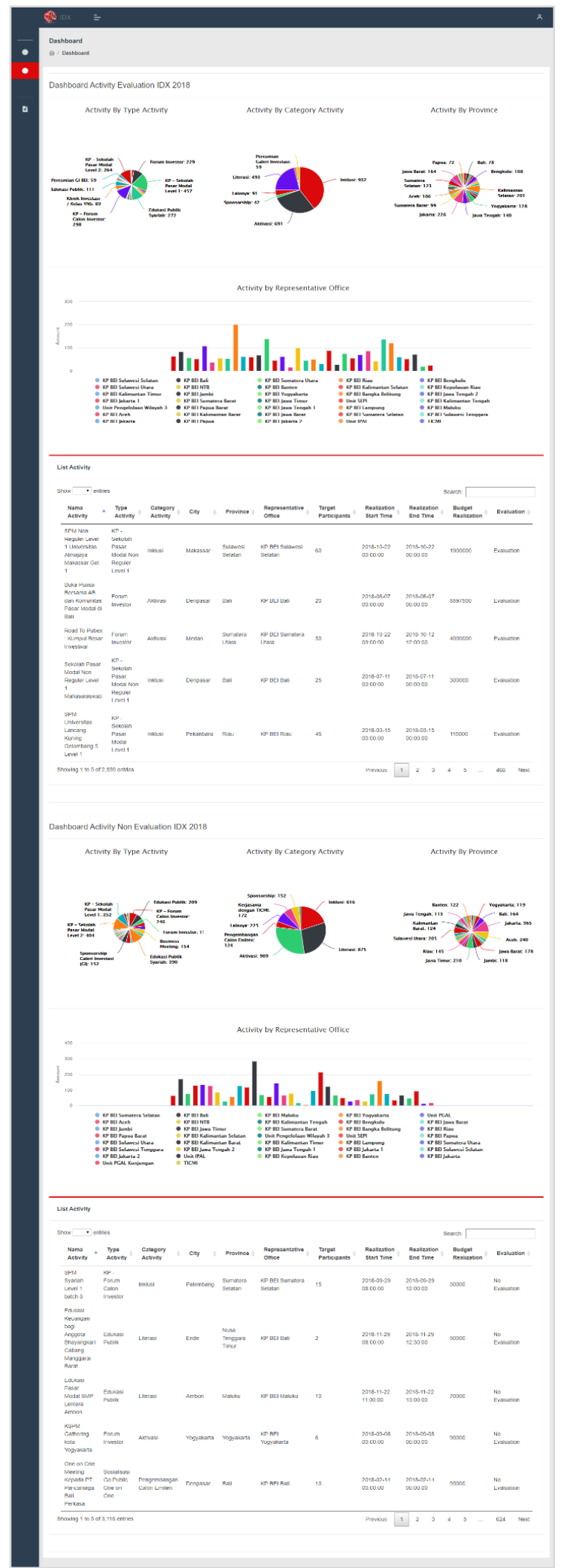

Fig. 23. Implementation Intelligence Dashboard Activity Evaluation 


\section{E. Testing Result}

Based on the results of the tests, the system can run and operate properly as expected. From data testing and training that has been compared to produce the expected output. Based on the desired usage scenario. Releasing functions that have been designed, can run well with enough good performance.

\section{Conslusion}

In this study, business intelligence system is expected to assist IDX in conducting evaluation activities. From the analysis of data that has been done can be concluded that the activities in each IDX representative office could potentially be evaluated. The realization of budgets and activity categories becomes the key to whether or not the activity is potentially evaluated. Fore this system can be redeveloped by adding a report feature that can be created in the form of a spreadsheet file or an image for example, so the output can be made easier in printing from the results of a built business intelligence.

\section{References}

[1] Rahmat Tri Yunandar, Amir and Khairul Rizal, "Perancangan Data Warehouse Untuk Informasi Strategi Studi Kasus Penerimaan Siswa Baru STIE Binaniaga Bogor", Journal of Computer Engineering AMIK BSI, Indonesia, Vol. 06, No.1, January 2020.

[2] Masdiana Sagala, "Implementasi Data Warehouse Pada Perpustakaan Universitas Katolik Santo Thomas", Journal Unika Informatics Engineering St. Thomas (JTIUST), Indonesia, Vol. 03, No.01, June 2018.

[3] Vishal Gour, Dr. S.S.Sarangdevot, Govind Singh Tanwar and Anand Sharma, "Improve Performance of Extract, Transform and Load (ETL) in Data Warehouse", International Journal on Computer Science and Engineering, Vol. 02, No.03, 2010.

[4] WANG Yijun and WANG Jun, "Application of Highcharts in the Analysis of the Multi-source Track Inspection Data", International Conference on Mechatronics, Electronic, Industrial and Control Engineering, 2015.

[5] Jin Bao Song, Jin Hong Song, Jian Ping Chai and Yue Yang, "Data Visualization of the Advertising Exchange Flow Statements Generation System on Demand Side Platform Based on Highcharts", MATEC Web of Conferences, 63, 05029 (2016).

[6] Ramos Somya and Setiawan Chandra Utama, "PERANCANGAN CUSTOMER RELATIONSHIP MANAGEMENT BERBASIS WEB DENGAN LIBRARY JQUERY RESPONSIVE DATATABLES”, Journal of Information Systems at Indagiri Islamic University, Indonesia, Vol. 08, No.9, September 2019.

[7] Budi Ramadhani, "KLASIFIKASI METODE NAIVE BAYES UNTUK KELANCARAN PEMBAYARAN KREDIT LEASING SEPEDA MOTOR", Technologia, Indonesia, Vol. 08, No.03, July - September 2017.

[8] Bustami, "PENERAPAN ALGORITMA NAIVE BAYES UNTUK MENGKLASIFIKASI DATA NASABAH ASURANSI", Journal Informathic Malikussaleh Releut University, Indonesia, Vol. 08, No.01, January 2014.

[9] Budi Harijanto, Yuri Ariyanto and Luthfia Miftahurroifa, "PENERAPAN ALGORITMA NAÏVE BAYES UNTUK KLASIFIKASI RETENSI ARSIP”, Journal Informathic Polinema Malang Polytechnic, Indonesia, Vol. 04, Edition.02, Februari 2018.

[10] Marhalim AR Walad Mahfuzhi and Sandhi Fernandes, Yuri Ariyanto and Luthfia Miftahurroifa, Pembuatan Aplikasi Pendukung Keputusan Beasiswa Tidak Mampu Dengan Metode Naive Bayes”, Muhammadiyah Bengkulus University, Indonesia.

[11] M. Golfarelli, S. Rizzi, and I. Cella, “Beyond Data Warehousing: What's Next In Business Intelligence?” in DOLAP '04, Washington DC, 2004

[12] S. Negash, and P. Gray, (2003). "Business Intelligence", in Americas Conference on Information Systems (AMCIS), 2003.

[13] Dedi Lazwardi, "IMPLEMENTASI EVALUASI PROGRAM PENDIDIKAN DI TINGKAT SEKOLAH DASAR DAN MENENGAH", Al-Idarah: Islamic Education Journal, Indonesia, Vol. 02, 2017.

[14] Saeed Rouhani, Sara Asgari and Seyed Vahid Mirhosseini, "Review Study: Business Intelligence Concepts and Approaches", American Journal of Scientific Research, 2012.

[15] Dr. H.M. Fauzan, S.H., M.H. and Baharuddin Siagian, S.H., M.Hum., "Kamus Hukum dan Yurisprudensi”, Kencana, Indonesia, 1182 pages, December 2016.

[16] Salwa Mohammed Nejres, “Analysis of Data Warehousing and Data Mining in Education Domain”, International Journal of Advances in Computer Science and Technology, Vol. 04, No.04, April 2015.

[17] Jan Van den Bussche., "Database Theory, Yuri, and Me", Kencana, Indonesia, January 2010.

[18] MATTEO GOLFARELLI, DARIO MAIO and STEFANO RIZZI, "THE DIMENSIONAL FACT MODEL: A CONCEPTUAL MODEL FOR DATA WAREHOUSES”, International Journal of Cooperative Information Systems, June 1998

[19] W. H. Inmon, "Building the Data Warehouse", Wiley, New York, NY, USA, 3rd edition, 2002.

[20] R. Kimball, L. Reeves, W. Thornthwaite, M. Ross, and W. Thornwaite, "The Data Warehouse Lifecycle Toolkit: Expert Methods for Designing, Developing and Deploying Data Warehouses, Wiley, New York, NY, USA, 1998.

[21] Pouria Kaviani and Mrs. Sunita Dhotre, "Short Survey on Naive Bayes Algorithm", International Journal of Advance Engineering and Research Development, Vol. 04, No.11, November 2017.

[22] Euis Nina Saparina Yuliani, Heru Subawanto and Anggi Oktaviani, "Business Intelligence Dashboard Implementation on a Travel Agency in Jakarta”, International Journal of Advanced Engineering Research and Science, Vol. 04, No. 6, June 2017

[23] Bernhard Wieder and Maria-Luise Ossimitz, "The impact of Business Intelligence on the quality of decision making - a mediation model”, Procedia Computer Science, October 2015 
[24] Shaheb Ali, Shah J. Miah and Shahadat Khan, "ANALYSIS OF INTERACTION BETWEEN BUSINESS INTELLIGENCE AND SMES: LEARN FROM EACH OTHER”, Journal of Information Systems and Technology Management, Vol. 14, No. 02, May/August 2017

[25] Pirttimäki V, Lönnqvist A, Karjaluoto A, "Measurement of business intelligence in a Finnish telecommunications company", Electron J Knowledge Management, 2006

[26] Azoff, M. and Charlesworth, I., "The New Business Intelligence, a European Perspective, Butler Group”, White Paper, 2004

[27] Muhmmad I. Nofal and Zawiyah M. Yusof, "Integration of Business Intelligence and Enterprise Resource Planning within Organizations", Procedia Technology, 2013

[28] Hergovind Singh and Harsh Vardhan Samalia, "A Business Intelligence Perspective for Churn Management", Procedia Technology, 2013

\section{Authors' Profiles}

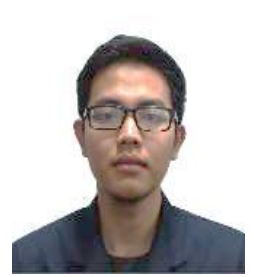

Ali Fajri is an Indonesian citizen with student status at Widyatama University. He also works in one of the IT companies in Indonesia in the area of Sarijadi (Bandung), working as a junior programmer. He can be contacted at ali.fajri@widyatama.ac.id.

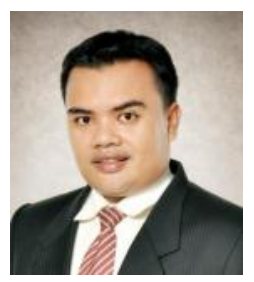

Ardiles Sinaga is currently serving as a Lecturer on the Department of Informatics at Widyatama University and Binus University, Indonesia. In 2013, he is completed his S2-Magister in Telkom University on Informatics Departement. He can be contacted at sinaga.diles@gmail.com.

How to cite this paper: Ali Fajri, Ardiles Sinaga, " Implementation of Business Intelligence to Determine Evaluation of Activities (Case Study Indonesia Stock Exchange)", International Journal of Information Engineering and Electronic Business(IJIEEB), Vol.12, No.6, pp. 51-67, 2020. DOI: 10.5815/ijieeb.2020.06.05 